\title{
An efficient method for isolating large quantity and high quality RNA from oleaginous microalgae for transcriptome sequencing
}

\author{
Anongpat Suttangkakul ${ }^{1,2}$, Piyada Juntawong ${ }^{1,2}$, Anchalee Sirikhachornkit ${ }^{1,2}$, Chonlada Yaisumlee ${ }^{1}$, \\ Kanid tha Jariyachawalid $^{3}$, Kunn Kangwansaichol ${ }^{3}$, Somsak Apisitwanich ${ }^{1,2}$, Supachai \\ Vuttipongchaikij ${ }^{1,2 *}$
}

${ }^{1}$ Special Research Unit in Microalgal Molecular Genetics and Functional Genomics (MMGFG), Department of Genetics, Faculty of Science, Kasetsart University, 50 Ngarm Wong Wan road, Chatuchak, Bangkok 10900, Thailand

${ }^{2}$ Center of Advanced studies for Tropical Natural Resources, Kasetsart University, 50 Ngam Wong Wan, Chatuchak, Bangkok 10900, Thailand

${ }^{3}$ PTT Research and Technology Institute, PTT Co., LTD., 71 Moo 2 Pahol Yothin road Wang Noi, Ayuthaya 13170, Thailand

\section{*Corresponding author: fsciscv@ku.ac.th}

\begin{abstract}
Transcriptome analysis requires a large quantity of high-quality DNase-treated RNA for poly(A)+ mRNA isolation and sequencing. This could be problematic in many oleaginous microalgal species that harbor strong cell walls and accumulate high lipid content. Using Scenedesmus obliquus, a microalga with high oil content and potential as a source of algal biofuel, we assessed the efficiency of four RNA isolation methods: direct extraction using TriPure, mechanical breakage using either freeze-thawed with bead beating or grinding in liquid nitrogen followed by TriPure, and grinding in liquid nitrogen before using Qiagen RNeasy Plant Mini Kit. Liquid nitrogen grinding with TriPure method gave the best RNA yields at $15.15 \mu \mathrm{g} \mathrm{mg}^{-1}$ cell dry weight and $\sim 148.9 \mu \mathrm{g}$ total RNA from $100 \mathrm{ml}$ culture of $S$. obliquus. Despite lower yields, RNA isolation of oil accumulating cells ( 22\% w/w lipid content) provided $\sim 68.1 \mu \mathrm{g}$ total RNA with the yield of $1.70 \mu \mathrm{g} \mathrm{mg}^{-1}$ cell dry weight. Transcriptome sequencing and de novo assembly with the average contig length of 824 bp reflected high quality of RNA obtained using this method. The RNA isolation protocol was tested on six other oleaginous microalgae including Chlamydomonas reinhardtii, S. acuminatus, Chorella vulgaris, Chlorococcum humicola, Tetradesmus cumbricus and Coelastrum sp. and yielded $0.86-5.42 \mu \mathrm{g} \mathrm{mg}^{-1}$ cell dry weight. For large scale RNA isolation from microalgae, grinding with liquid nitrogen before TriPure provided the best yield and quality. This finding helps simplify RNA isolation for upcoming transcriptome analyses in microalgae.
\end{abstract}

Keywords: Biofuel; Oil-rich cells; RIN; RNA isolation; Scenedesmus obliquus.

Abbreviations: bp_base pair; CTAB_Cetyltrimethylammonium bromide; DEPC_Diethylpyrocarbonate; RIN_RNA integrity; TAP_ Tris-Acetate-Phosphate.

\section{Introduction}

Quantity and quality of RNA samples are crucial factors for transcriptome sequencing. As proposed for transcriptome analysis in plants and algae using Illumina's GAIIx and HiSeq sequencing platforms, a standard procedure requires up to 20 micrograms of a DNase-treated RNA sample for isolating poly $(\mathrm{A})+\mathrm{RNA}$, which will be used for library construction (Johnson et al., 2012). Likewise, the RNA is required to be of high quality, referred to RNA integrity (RIN) (Schroeder et al., 2006) and 28S/18S rRNA ratio (Sambrook and Russell, 2001) as indicators, to ensure the quality of obtaining data. With the ability to produce lipids, eukaryotic microalgae emerged as a potential source for renewable and sustainable energy. Transcriptome has been providing global gene expression data and many valuable candidate genes for microalgal genetic improvement in past recent years (Guarnieri et al., 2011; Lv et al., 2013). However, most of the oleaginous microalgae have cellulosic cell walls similar to those of higher plants, which are difficult to break and cause a difficulty for RNA isolation (Domozych et al., 2012). Moreover, the high content of accumulated lipids could result in very low RNA yields or low quality poly(A)+ RNA, unsuitable for subsequent applications (Sangha et al., 2010; Dang et al., 2013). Thus, a method for efficient RNA isolation has to be developed for microalgae under various cell conditions. Apart from commercial RNA isolation kits, a number of RNA isolation methods used for microalgae have been demonstrated. For Chlamydomonas and Volvox, RNA was efficiently isolated by direct extraction using phenol or monophasic solution of phenol and guanidine isothiocyanate (Kirk and Kirk, 1985; Simon et al., 2013). For other green microalgae, however, a step of cell disruption is crucially required prior to the extraction step. The means of cell disruption used in the past included grinding in liquid nitrogen using mortar and pestle as demonstrated in Ankistrodesmus convolutus (Thanh et al., 2009) and 
vigorously shaking with glass or metal beads using a beating machine in combination with freeze-thawing in Dunaliella tertiolecta (Rismani-Yazdi et al., 2011) and Botryococcus spp. (Kim et al., 2012). Although there were a number of reports of successful transcriptome sequencing from oleaginous microalgae including Botryococcus (Baba et al., 2013) and Haematococcus (Gwak et al., 2014), most reports did not demonstrate the efficiency of their methods for isolating a large quantity of RNA from oil accumulating microalgae. Here we initially tested four RNA isolation methods including direct extraction using TriPure Isolation Reagent, freeze-thawed with bead-beater followed by TriPure (FBT), grinding in liquid nitrogen followed by TriPure (LNT), and grinding in liquid nitrogen followed by Qiagen RNeasy Plant Mini Kit (LNK) on a species of oil producing green microalga, Scenedesmus obliquus. The LNT method, which gave the highest yield among the four, was then tested on oil accumulating cells of $S$. obliquus. Quality of the isolated RNA was confirmed to be suitable for transcriptome sequencing by assessing the $28 \mathrm{~S} / 18 \mathrm{~S}$ rRNA ratio and RNA integrity number. The quality of transcriptome sequences was subsequently verified by de novo assembly and RT-PCR. Finally, we further tested applicability of the LNT method on other oleaginous microalgae including Chlamydomonas reinhardtii, Chlorella vulgaris, Scenedesmus sp., Chlorococcum humicola, Coelastrum sp., and Tetradesmus cumbricus.

\section{Results}

\section{Comparison of four RNA isolation methods on S. obliquus}

We tested four RNA isolation methods; direct TriPure extraction, FBT, LNT and LNK on S. obliquus to identify the best method for isolating a large quantity of high quality RNA for transcriptome sequencing. The quality of total RNA analyzed by agarose gel electrophoresis is presented in Fig 1. Bands corresponding to $28 \mathrm{~S}$ and $18 \mathrm{~S}$ rRNA were clearly visible in RNA samples obtained from FBT, LNT and LNK methods, but not from direct TriPure extraction. Clearly, direct TriPure extraction was inefficient for RNA isolation for this species, and this method was excluded from further analysis. Moreover, RNA obtained using the LNK method had less of RNA with size smaller than 1,000 bp. This bias could be due to the column binding ability and might affect the transcriptome sequencing result. Concentration and purity of the RNA samples calculated from $\mathrm{OD}_{260}, \mathrm{OD}_{280}$ and $\mathrm{OD}_{230}$ are shown in Table 1 . Using approximately $10 \mathrm{mg}$ of cell materials, the LNT method provided the highest total RNA, ranged from 20 to $148 \mu \mathrm{g}$, whereas FBT and LNK methods gave much lower amounts, ranged from 7 to $14.6 \mu \mathrm{g}$ and 45.8 to $58.8 \mu \mathrm{g}$, respectively. Given the standard ratios of $\mathrm{OD}_{260 / 280}$ and $\mathrm{OD}_{260 / 230}$ around 1.8 and 2, respectively, for high quality RNA with minimum impurity (Gallagher and Desjardins, 2006), the ratios of isolated RNA from these three methods were in the same ranges and indicated trace amounts of impurity. After DNase treatment and column purification, the quality of the RNA was re-assessed by RNA gel electrophoresis (Fig 1) and $\mathrm{OD}_{260}, \mathrm{OD}_{280}$ and $\mathrm{OD}_{230}$ (Table 1). The results showed that the RNA was of high purity with minimum degradation. The amounts of total RNA after DNase treatment indicated that the LNT method was robust and highly efficient, yielding up to $\sim 55 \mu \mathrm{g}$ total RNA, approximately 7 -fold and 2 -fold higher than those obtained from FBT and LNK methods, respectively. The RNA yields from LNT before and after DNase treatment and column purification were 2.2-15.15 $\mu \mathrm{g} \mathrm{mg}^{-1} \mathrm{DW}$ and 0.67-5.65 $\mu \mathrm{g}$ $\mathrm{mg}^{-1} \mathrm{DW}$, respectively.

\section{RNA isolation from oil rich cells of S. obliquus}

To test the efficiency of RNA extraction by the LNT method on oil rich microalgal cells, RNA was isolated from $S$. obliquus, which was cultured under nitrogen-deprivation, a commonly used condition for inducing lipid accumulation in microalgae. The lipid content in these cells was approximately $21 \%(\mathrm{w} / \mathrm{w})$, as quantified by the Bligh and Dryer method. After RNA gel electrophoresis, bands representing $28 \mathrm{~S}$ and $18 \mathrm{~S}$ rRNA were clearly detected in the RNA isolated from oil rich cells, even though the band intensity was much lower than that from log phase cells (Fig 2). Total RNA obtained from $200 \mathrm{ml}$ of culture grown in TAP-N media was approximately 50-80 $\mu \mathrm{g}, \sim 4$-fold less than that isolated from $100 \mathrm{ml}$ of cultures grown in TAP media (Table 2). The RNA yield from TAP-N was $\sim 4$-fold less than that from TAP. Analysis of $\mathrm{OD}_{260 / 280}$ and $\mathrm{OD}_{260 / 230}$ ratios implied that RNA isolated from oil rich cells (TAP-N) contained more impurities than the RNA isolated from log phase cells (TAP). However, after the treatment with DNase and purification using RNA column, the quality of RNA was improved as indicated by $\mathrm{OD}_{260 / 280}$ and $\mathrm{OD}_{260 / 230}$ ratios. This result indicates that the LNT method can be used for isolating RNA from oil rich cells of $S$. obliquus, but at less quantity and lower quality than those obtained from log phase cells.

\section{RNA quality assessments by RIN, rRNA ratio, de novo transcriptome sequencing and RT-PCR}

To further verify the RNA quality for transcriptome sequencing, two technical replicates of each biological RNA sample were combined and analyzed using a Bioanalyzer. Electropherograms of RNA profiles are presented in Fig 3. rRNA ratio and RIN calculated from the profiles demonstrated the quality assessments of the RNA for subsequent de novo transcriptome sequencing. 28S/18S rRNA ratio of RNA from TAP and TAP-N samples (1.5-1.6) indicated that the integrity of the RNA samples were considered intact, giving that the ratio of high quality and partially degraded RNA samples are about 2.0 and 1.0, respectively (Sambrook and Russell, 2001). Nonetheless, RIN analysis, which derived from the whole RNA profile, indicated that the integrity of RNA from TAP samples (RIN $=8.0-8.1$ out of 10) were at higher levels than those from TAP-N samples $(\mathrm{RIN}=6.3)$. This data reflects that RNA isolated from $S$. obliquus cells accumulating oils under stress conditions might be more prone to RNA degradation than those isolated from log phase cells. De novo sequencing of DNase-treated RNA samples from $S$. obliquus grown under nitrogen $(\mathrm{N})$ and nitrogen-deprivation $(-\mathrm{N})$ conditions yielded 43-52 million raw read sequences, equivalent to $\sim 4.3-5.2 \mathrm{Mb}$, among the four libraries (Table 3 ). The average length of each paired-end read was $100 \mathrm{bp}$. The read pairs were filtered for a pre-assembly process and yielded 42-49 million high quality reads, as indicated by $\mathrm{Q} 20$ and $\mathrm{Q} 30$. De novo assembly of the filtered sequences using the Trinity resulted in consensus transcriptome of 51,846 transcript contigs (Table 4). Among these, 47,192 transcripts were unique with the length ranging from 201 to $10,302 \mathrm{bp}$ and an average length of $824 \mathrm{bp}$. In the $S$. obliquus transcriptome data, the expression of STA1 and STA6 was reduced during nitrogen starvation, coinciding with those observed in the Chlamydomonas (Miller et al., 2010). To confirm the expression reduction and further test the quality of RNA, we performed RT-PCR analysis of starch biosynthesis genes STA1 and STA6 and a house keeping gene, Ubiquitin (UBI), using primers based on the assembled contigs. RT-PCR 
Table 1. Quantity and quality of RNA isolated from Scenedesmus obliquus using LNK, FBT and LNT methods. DNase treatment was followed by column purification. Each method was performed in triplicate.

\begin{tabular}{|c|c|c|c|c|c|c|c|c|c|}
\hline \multirow{2}{*}{$\begin{array}{l}\text { Extraction } \\
\text { method }\end{array}$} & \multicolumn{5}{|c|}{ Before DNase treatment } & \multicolumn{4}{|c|}{ After DNase treatment } \\
\hline & RNA concentration $\left(n g \mu 1^{-1}\right)$ & Total RNA $(\mu \mathrm{g})$ & RNA yield $\left(\mu \mathrm{g} \mathrm{mg}^{-1} \mathrm{DW}\right)$ & $\mathrm{OD}_{260 / 280}$ & $\mathrm{OD}_{260 / 230}$ & RNA concentration $\left(\mathrm{ng} \mu \mathrm{l}^{-1}\right)$ & Total RNA $(\mu \mathrm{g})$ & RNA yield $\left(\mu \mathrm{g} \mathrm{mg}^{-1} \mathrm{DW}\right)$ & $\mathrm{OD}_{260 / 280}$ \\
\hline $\mathrm{LNK}^{\mathrm{a}}$ & $2,098.6$ & 62.96 & 5.59 & 2.18 & 2.39 & 553.6 & 27.68 & 2.46 & 2.20 \\
\hline $\mathrm{LNK}_{2}{ }^{\mathrm{a}}$ & $1,637.3$ & 49.12 & 4.36 & 2.19 & 2.35 & 548.0 & 27.40 & 2.43 & 2.18 \\
\hline $\mathrm{LNK}^{\mathrm{a}}{ }^{\mathrm{a}}$ & $1,694.6$ & 50.84 & 4.52 & 2.18 & 2.45 & 436.8 & 21.84 & 1.94 & 2.17 \\
\hline $\mathrm{FBT}^{\mathrm{b}}$ & 487.7 & 14.63 & 1.49 & 1.96 & 0.80 & 146.2 & 7.31 & 0.74 & 2.13 \\
\hline $\mathrm{FBT}^{\mathrm{b}}$ & 260.6 & 7.82 & 0.80 & 1.72 & 0.39 & 47.6 & 2.38 & 0.24 & 2.08 \\
\hline $\mathrm{FBT}^{\mathrm{b}}$ & 447.9 & 13.44 & 1.37 & 1.81 & 0.47 & 135.9 & 6.795 & 0.69 & 2.12 \\
\hline $\mathrm{LNT}^{\mathrm{b}}$ & 3,417 & 102.51 & 10.42 & 1.91 & 0.84 & 1110.8 & 55.54 & 5.65 & 2.16 \\
\hline $\mathrm{LNT}^{\mathrm{b}}$ & $4,965.9$ & 148.98 & 15.15 & 2.05 & 1.53 & 1086.9 & 54.345 & 5.53 & 2.17 \\
\hline LNT3 $^{\mathrm{b}}$ & 727.7 & 21.83 & 2.22 & 1.73 & 0.67 & 131.7 & 6.585 & 0.67 & 2.13 \\
\hline
\end{tabular}

Table 2. Quantity and quality of RNA isolated from log phase cells (TAP) and oil rich cells (TAP-N) of S. obliquus using LNT method. Two biological replicates were used for each cell condition, and each biological replicate was equally divided into two technical replicates.

\begin{tabular}{|c|c|c|c|c|c|}
\hline Samples & RNA concentration $\left(\mathrm{ng} \mu \mathrm{l}^{-1}\right)$ & Total RNA $(\mu \mathrm{g})$ & RNA yield $\left(\mu \mathrm{g} \mathrm{mg}^{-1} \mathrm{DW}\right)$ & $\mathrm{OD}_{260 / 280}$ & $\mathrm{OD}_{260 / 230}$ \\
\hline TAP1-1 ${ }^{\mathrm{a}}$ & 8,525 & 255.75 & 7.43 & 2.10 & 1.70 \\
\hline TAP1-2 ${ }^{a}$ & 7,228 & 216.84 & 6.30 & 2.08 & 1.50 \\
\hline TAP2- $1^{\mathrm{b}}$ & 9,196 & 275.88 & 4.22 & 2.11 & 1.75 \\
\hline TAP2-2 ${ }^{\mathrm{b}}$ & 10,153 & 304.59 & 4.66 & 2.14 & 2.07 \\
\hline TAP-N1-1 & 2,727 & 81.81 & 1.34 & 1.84 & 0.47 \\
\hline TAP-N1-2 ${ }^{c}$ & 1,898 & 56.94 & 0.93 & 1.64 & 0.38 \\
\hline TAP-N2-1 & 1,651 & 49.53 & 1.23 & 1.62 & 0.55 \\
\hline TAP-N2-2 ${ }^{\mathrm{d}}$ & 2,270 & 68.1 & 1.70 & 1.79 & 0.47 \\
\hline
\end{tabular}



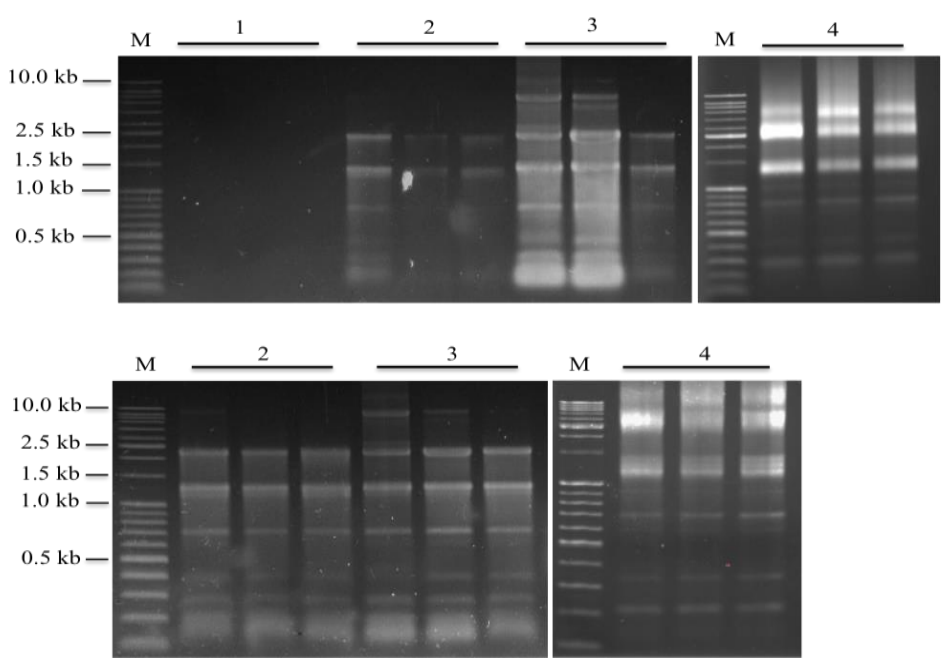

Fig 1. Gel electrophoresis of RNA isolated from S. obliquus using four methods. (Upper panel) Isolated RNA using direct TriPure Isolation Reagent (1), FBT (2), LNT (3) and LNK using Qiagen RNeasy Plant Mini Kit. Three replicates of each RNA isolation methods are presented. (Lower panel) RNA samples after DNase-treatment followed by column-purification $(1 \mu \mathrm{g})$ from each method.

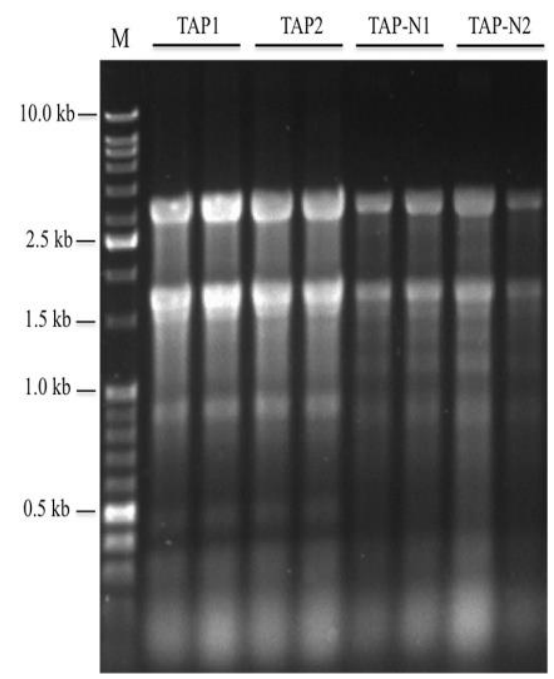

Fig 2. Gel electrophoresis of RNA isolated from log-phase cells (TAP) and oil accumulating cells (TAP-N). RNA was extracted from S. obliquus using the LNT method. Two biological replicates were used for each condition, with two technical replicates each.

confirmed that the expression of STA1 and STA6 was reduced in the nitrogen starvation condition (Fig 4). Taken together with the transcriptome data, these results indicated that, even from oil rich samples, the quality of RNA extracted using the LNT method is sufficient for transcriptome sequencing and RT-PCR expression analysis.

\section{RNA isolation of six oleaginous microalgae using $L N T$ method}

To assess whether this LNT method can be efficiently applied to other oleaginous microalgae, we determined the quality and quantity of RNA extracted from six other microalgal species, $C$. reinhardtii, $S$. accuminatus, $C$. humicola and T. cumbricus, C. vulgaris and Coelastrum sp.. The RNA concentration obtained ranged from 800 to 4,500 ng $\mu \mathrm{g}^{-1}$, with the total RNA ranged from 25 to $135 \mu \mathrm{g}$, as listed in Table 5. The quality of total RNA analyzed by gel electrophoresis is shown in Fig 5. These results demonstrate that the LNT method can efficiently isolate high quality RNA from all six species tested. After DNase treatment, the bands with size larger than $10 \mathrm{~kb}$ representing DNA contaminants disappeared, while the $28 \mathrm{~S}$ and $18 \mathrm{~S}$ bands were still clearly detected. Total RNA obtained after DNase treatment ranged from 12 to $45 \mu \mathrm{g}$, and these were sufficient for transcriptome sequencing and subsequent analyses. From our result, RNA yields after DNase treatment varied from 0.4 to $2.94 \mu \mathrm{g} \mathrm{mg}^{-1}$ cell dry weight.

\section{Discussion}

Generally for transcriptome analysis, up to $20 \mu \mathrm{g}$ of DNasetreated RNA is required for quality assessments, library construction and sequencing (Johnson et al., 2012). Our data suggests that, in order to obtain sufficient amount of DNasetreated RNA, microalgal materials ranging from 1.32 to 50 mg cell dry weight may be required for RNA isolation using the LNT method. From the first round of extraction, the 
Table 3. De novo transcriptome sequencing of RNA isolated from $S$. obliquus under TAP and TAP-N conditions using the LNT method. Raw reads represented by total bases and read count both prior and after adaptor eliminations (filtered) are presented. Q20 and Q30 represent the quality of reads at $p<0.01$ and $p<0.001$, respectively.

\begin{tabular}{lccccc}
\hline & Total bases & $\begin{array}{c}\text { Read count } \\
\text { (transcripts) }\end{array}$ & GC (\%) & Q20 (\%) & Q30 (\%) \\
\hline TAP1 & $4,381,903,988$ & $43,385,188$ & 59.01 & 96.65 & 92.33 \\
TAP2 & $4,700,417,386$ & $46,538,786$ & 58.95 & 97.05 & 93.04 \\
TAP-N1 & $4,605,285,890$ & $45,896,890$ & 56.69 & 95.59 & 89.83 \\
TAP-N2 & $5,260,100,806$ & $52,080,206$ & 55.73 & 95.27 & 89.19 \\
TAP1-filtered & $4,157,955,070$ & $42,013,340$ & 58.87 & 99.28 & 95.49 \\
TAP2-filtered & $4,492,176,776$ & $45,318,070$ & 58.81 & 99.34 & 95.79 \\
TAP-N1-filtered & $4,294,574,976$ & $43,708,442$ & 56.6 & 98.93 & 93.8 \\
TAP-N2-filtered & $4,874,702,124$ & $49,650,100$ & 55.63 & 98.86 & 93.48 \\
\hline
\end{tabular}

Table 4. De novo assembly of transcriptome sequencing obtained from four isolated RNA samples of S. obliquus under both TAP and TAP-N conditions.

\begin{tabular}{lcc}
\hline & All transcript contigs & Only longest isoform per gene \\
\hline Total trinity genes & 47,192 & 47,192 \\
Total trinity transcripts & 51,846 & 47,192 \\
Maximum contig length (bases) & 10,302 & 10,302 \\
Minimum contig length (bases) & 201 & 201 \\
Median contig length (bases) & 469 & 445 \\
Average contig length (bases) & 824.21 & 788.02 \\
Total assembled bases & $42,732,046$ & $37,188,214$ \\
\hline
\end{tabular}

concentration of RNA obtained from seven microalgal

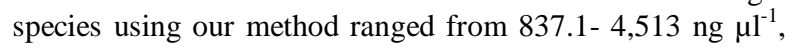
and the amount of total RNA was equivalent to 25.11-135.39 $\mu \mathrm{g}$. After DNase treatment and subsequent purification, RNA

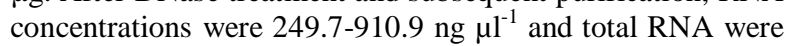
$12.485-45.55 \mu \mathrm{g}$. Quality and purity of the RNA were assured by $\mathrm{OD}_{260}, \mathrm{OD}_{280}$ and $\mathrm{OD}_{230}$. The RNA yields obtained from oil accumulating cells was $\sim 4$ fold less than those generally obtained from active growing cells, suggesting that much more cell material of oil rich cells is required for RNA isolation. The quantity and quality of selected RNA samples analysed further by $28 \mathrm{~S} / 18 \mathrm{~S}$ ratio, $\mathrm{RIN}$, de novo transcriptome sequencing and RT-PCR affirmed that the RNA obtained by the LNT method could be used for transcriptome sequencing. A recent work by Kim et al. (2012) compared the efficiency in DNA and RNA isolations from Botryococcus spp. among different methods and demonstrated that the most efficient extraction method, using freeze-thawed followed by bead beating, provided the highest RNA yields approximately 15 to $34 \mu \mathrm{g}$ per 1.17 to $2.42 \mathrm{mg}$ cell dry weight of algal mass. However, this freezethawed and bead-beating method was suggested to be more suitable for screening tasks. Another report with RNA yields provided is the work by Thanh et al. (2009), which isolated RNA from $A$. convolutus by grinding in liquid nitrogen followed by CTAB extraction. The RNA yields obtained from A. convolutus were $0.69-0.73 \mu \mathrm{g} \mathrm{mg}^{-1}$ cell fresh weight, whereas, in our hands, the yields obtained from $S$. obliquus were 2.22 to $15.15 \mu \mathrm{g} \mathrm{mg}^{-1}$ cell dry weight. Even though we cannot directly compare the yields due to the difference of microalgal species used, we can infer that grinding in liquid nitrogen is the preferred method for microalgal cell breaking and RNA isolation, when a large quantity of RNA is required. Besides the higher yields compared to freezethawed and bead-beating as shown in our work, this grinding in liquid nitrogen method only requires mortar and pestle without other expensive equipment, making it suitable for small labs with limited funding. This method is also easy to scale up, whereas scaling up an extraction using beat-beater would require splitting large volume samples into many small tubes for processing. However, this technique does have a drawback in yield inconsistency among samples. Since the grinding step was manually conducted using mortar and pestle, some tissue loss might occur both when transferring samples onto the mortar and during the grinding step, leading to low yields in some samples. In addition to the cell breaking method, the extraction reagent is another factor to be considered. RNA isolation of S. obliquus with oil content up to $20 \%(\mathrm{w} / \mathrm{w})$ using TriPure Isolation Reagent indicated that this reagent could be used for isolating RNA from oil rich cell conditions at sufficient quantity and quality for transcriptome sequencing. However, the yields were much lower than those obtained from active growing cells. This is also the case for transcriptome sequencing of microalgae Myrmecia incisa Reisigl H4301 (Ouyang et al., 2013) and Botryosphaerella sudeticus (Sun et al., 2013). The efficiency of the phenol-guanidinium isothiocyanate reagents 

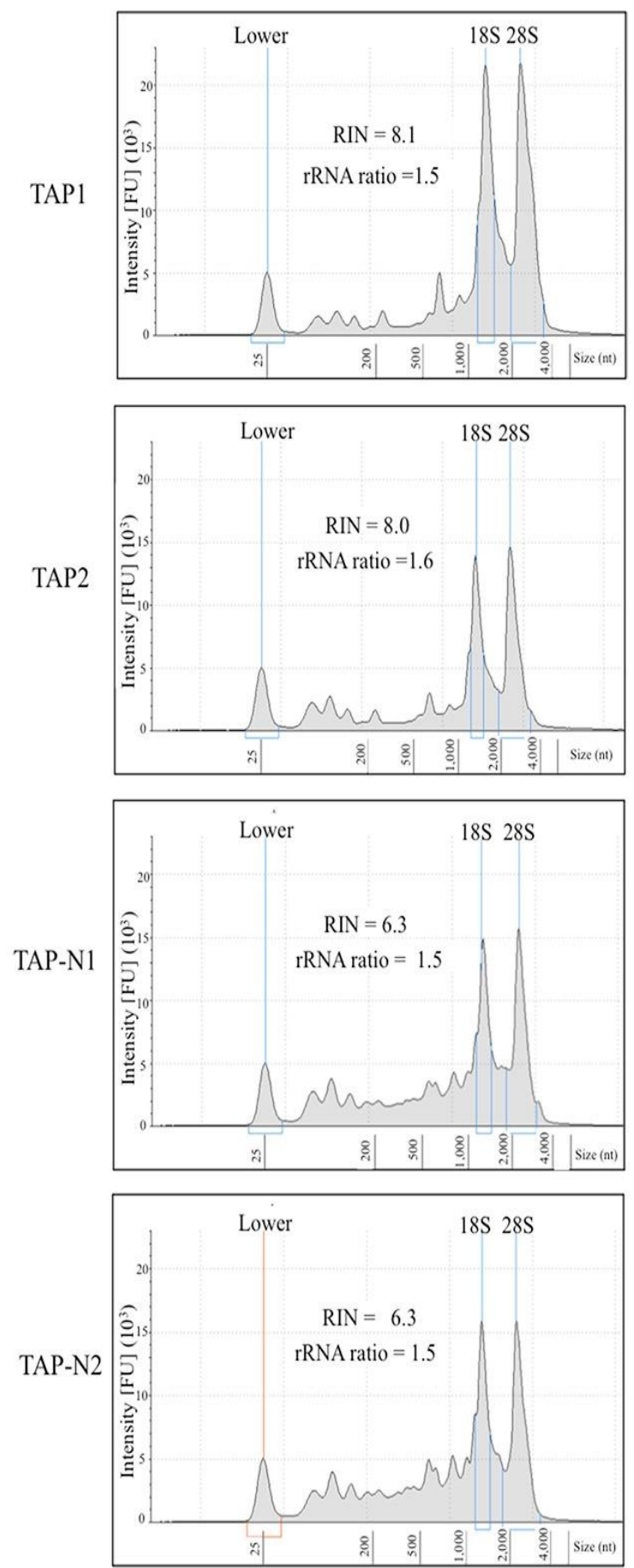

Fig 3. Electropherograms of RNA isolated from log-phase cells (TAP) and oil accumulating cells (TAP-N). RNA was extracted from $S$. obliquus using the LNT method. Two biological replicates were used for each condition. RIN and $28 \mathrm{~S} / 18 \mathrm{~S}$ rRNA ratios are indicated within the graph. The $18 \mathrm{~S}$ and $28 \mathrm{~S}$ peaks were marked, as well as the lower marker.

for isolating RNA from cells with higher oil content is left to be determined. The extraction reagent used for Qiagen RNeasy Plant Mini Kit is similar to TriPure since the extraction buffer for the kit contains guanidine isothiocyanate. Therefore, the reduction in the abundance of the smaller size RNA when extracted using the kit should be due to the column used. Even though the kits are easier to use compared to TriPure extraction, using Qiagen RNeasy Plant

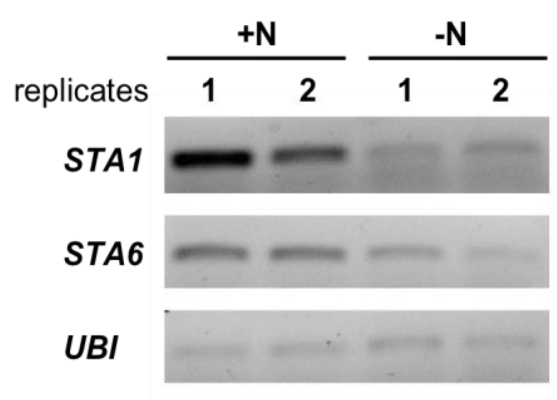

Fig 4. RT-PCR of STAI and STA6 from cells grown in media with and without nitrogen. RNA was from two biological replicates. UBI was used as a RNA loading control.

Mini Kit for RNA preparation for transcriptome sequencing might not be appropriate because of the bias against smaller size RNA, which could affect the transcriptome data analysis.High quality RNA helps in obtaining long transcripts since there will be more overlapping sequences for contig assembly (Johnson et al., 2012). In particular, the length of transcript is very important for transcriptome analysis in species with no reference genome sequence. From our sequencing data, the contig lengths were somewhat in the middle of those previously reported for transcriptome sequencing in microalgae. For examples, so far, the longest average contig length was from Neochloris oleoabundans with 1,459 bp (Rismani-Yazdi et al., 2012), whereas the shortest length was from Botryococcus braunii with 296 bp (Baba et al., 2012). Although the number of read sequences and total read bases could not be used for inferring the RNA quality as these are limited by the sequencing apparatus and techniques, RNA samples isolated using our method provided transcriptome reads with sufficient quality for de novo assembly. Various oleaginous green microalgae harbour strong cellulosic cell walls (Domozych et al., 2012), which are problematic for nucleic acid isolation and oil extraction. Currently, no technical guideline is available for RNA preparation for transcriptome sequencing from oleaginous microalgae. In our work, as seven species were tested for RNA extraction efficiency, we provide an estimate of starting cell materials required for the task. To obtain $20 \mu \mathrm{g}$ of purified DNase-treated RNA, one would need at most $50 \mathrm{mg}$ cell dry weight of microalgae. This amount of microalgal mass could be easily acquired from less than $400 \mathrm{ml}$ of microalgal culture.

\section{Materials and Methods}

\section{Microalgal strains and culture conditions}

S. obliquus, C. vulgaris, S. acuminatus, C. humicola and $T$. cumbricus were obtained from Thailand Institute of Science and Technology Research (TISTR), and Coelastrum sp. was obtained from Prof. Juergen Polle (Brooklyn College). $C$. reinhardtii strain $4 \mathrm{~A}+$ was used in this study. All microalgal species were cultured in TAP medium for 3-4 days at $25^{\circ} \mathrm{C}$ under continuous light $\left(50 \mu \mathrm{mol}\right.$ photons $\left.\mathrm{m}^{-2} \mathrm{~s}^{-1}\right)$ with continuous shaking. For each experiment, the microalgae were grown in 300-400 ml culture volume to mid-log phase, and $100 \mathrm{ml}$ and $200 \mathrm{ml}$ of the culture were used for RNA isolation from TAP and TAP medium without nitrogen supplements (TAP-N), respectively. 
Table 5. Quantity and quality of RNA isolated from six microalgal species using LNT method, both before and after DNase treatment. Two biological replicates were performed for each microalgal species. Recovery yield presents the percentage of RNA recovered after the DNase treatment and column purification.

\begin{tabular}{|c|c|c|c|c|c|c|c|c|c|}
\hline \multirow{2}{*}{ Species } & \multicolumn{3}{|c|}{ Before DNase treatment } & \multicolumn{5}{|c|}{ After DNase treatment } & \multirow{2}{*}{$\begin{array}{c}\text { Recover } \\
\text { y yield } \\
(\%)\end{array}$} \\
\hline & $\begin{array}{l}\text { RNA concentration } \\
\qquad\left(n g \mu 1^{-1}\right)\end{array}$ & $\begin{array}{l}\text { Total RNA } \\
\quad(\mu \mathrm{g})\end{array}$ & $\begin{array}{l}\text { RNA yield } \\
(\mu \mathrm{g} / \mathrm{mg} \mathrm{DW})\end{array}$ & $\begin{array}{l}\text { RNA concentration } \\
\quad\left(\text { ng } \mu 1^{-1}\right)\end{array}$ & $\begin{array}{l}\text { Total RNA } \\
\quad(\mu \mathrm{g})\end{array}$ & $\begin{array}{c}\text { RNA yield } \\
\left(\mu \mathrm{g} \mathrm{mg}^{-1} \mathrm{DW}\right)\end{array}$ & $\mathrm{OD}_{260 / 280}$ & 230 & \\
\hline C. reinhardtii $1^{\mathrm{a}}$ & $1,383.5$ & 41.51 & 1.95 & 517.8 & 25.89 & 1.21 & 2.07 & 2.15 & 62.37 \\
\hline C. reinhardtii $2^{\mathrm{a}}$ & $1,859.5$ & 55.79 & 2.60 & 504.4 & 25.22 & 1.18 & 2.06 & 2.09 & 45.21 \\
\hline S. acuminatus $2^{\mathrm{b}}$ & $2,952.2$ & 88.57 & 3.55 & 313.7 & 15.685 & 0.63 & 2.15 & 2.41 & 17.71 \\
\hline C. humicola $1^{\mathrm{c}}$ & $2,388.4$ & 71.65 & 4.63 & 910.9 & 45.55 & 2.94 & 2.15 & 2.27 & 63.57 \\
\hline C. humicola $2^{\mathrm{c}}$ & $1,725.4$ & 51.76 & 3.35 & 520 & 26.0 & 1.68 & 2.09 & 2.18 & 50.23 \\
\hline T. cumbricus $1^{\mathrm{d}}$ & $1,582.4$ & 47.47 & 1.22 & 309.8 & 15.490 & 0.40 & 2.16 & 2.38 & 32.63 \\
\hline T. cumbricus $2^{\mathrm{d}}$ & $2,321.9$ & 69.66 & 1.78 & 355.6 & 17.780 & 0.46 & 2.15 & 2.40 & 25.52 \\
\hline C. vulgaris $2^{\mathrm{e}}$ & $2,163.4$ & 64.90 & 2.86 & 249.7 & 12.485 & 0.55 & 2.16 & 2.45 & 19.24 \\
\hline Coelastrum sp. $1^{\mathrm{f}}$ & 837.1 & 25.11 & 0.86 & 424.3 & 21.22 & 0.73 & 2.08 & 2.07 & 84.51 \\
\hline Coelastrum sp. $2^{\mathrm{f}}$ & $1,229.4$ & 36.88 & 1.26 & 679.1 & 33.96 & 1.16 & 2.18 & 2.30 & 92.08 \\
\hline
\end{tabular}

${ }^{a} 21.33 \mathrm{mg}$ cell dry weight used for extraction, ${ }^{\mathrm{b}} 24.97 \mathrm{mg} .{ }^{\mathrm{c}} 15.47 \mathrm{mg} .{ }^{\mathrm{d}} 39.07 \mathrm{mg} .{ }^{\mathrm{e}} 22.70 \mathrm{mg} .{ }^{\mathrm{f}} 29.26 \mathrm{mg}$ 


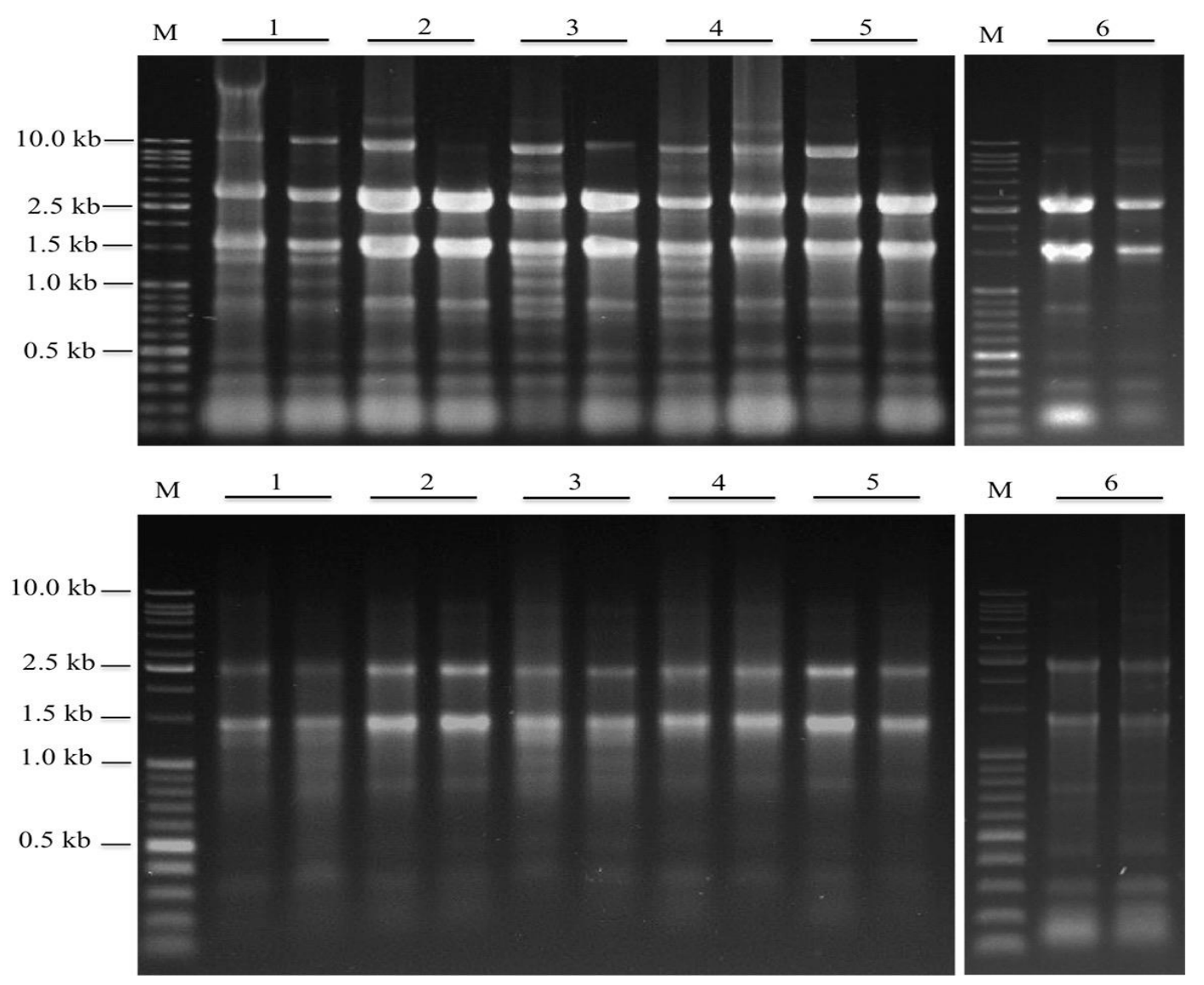

Fig 5. Gel electrophoresis of RNA isolated from microalgae C. reinhardtii (1), S. accuminatus (2), C. humicola (3), T. cumbricus (4), C. vulgaris (5) and Coelastrum sp. (6). (Upper panel) One out of $30 \mu \mathrm{l}$ of RNA extracted using the LNT method, before DNase treatment. (Lower panel) One microgram of RNA obtained after DNase-treatment and column-purification of each RNA samples. Two technical replicates were performed for each microalgal species. 
For the algal dry weight, $100 \mathrm{ml}$ of each culture was washed

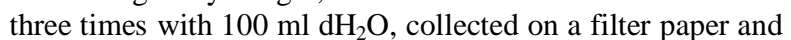
dried at $60^{\circ} \mathrm{C}$ for three days before measurements. For induction of lipid accumulation, the mid-log phase cultures were transferred into TAP-N and cultured under the same conditions for two days before being harvested.

\section{Lipid quantification}

The lipid content was measured using the Bligh and Dryer method. Briefly, microalgal cells were washed three times using $\mathrm{dH}_{2} \mathrm{O}$ at the culture volume with an interval of centrifugations at $2,000 \times \mathrm{g}$ for $10 \mathrm{~min}$, collected and dried at $60^{\circ} \mathrm{C}$ for three days. The weight of the cell pellets was measured before the lipid extraction. Lipids were extracted three times using $2 \mathrm{ml}$ chloroform:methanol (2:1) and sonication for $30 \mathrm{~s}$ for each extract. The extracts were then air-dried. The percentage of total lipids was calculated using the weight of total lipid extracts against the dry weight of the algal mass.

\section{RNA isolation}

One hundred millilitres of microalgal cultured cells were harvested by centrifugation at $2,000 \times \mathrm{g}$ for $10 \mathrm{~min}$ and subjected to direct extraction using TriPure Isolation Reagent (Roche), freeze thawed with bead beating or grinding with liquid nitrogen followed by TriPure and grinding with liquid nitrogen followed by Qiagen RNeasy Plant Mini Kits. For direct extraction, the cell pellet was resuspended in $1 \mathrm{ml}$ TriPure Isolation Reagent before being thoroughly mixed with $200 \mu 1$ chloroform by repeatedly inverting the tube. The sample was then centrifuged at $12,400 \times \mathrm{g}$ for $10 \mathrm{~min}$ and the upper layer was carefully transferred into a new $1.5 \mathrm{ml}$ micro tube. RNA was then precipitated by adding an equal volume of isopropanol, mixed and incubated at $-20^{\circ} \mathrm{C}$ overnight. The RNA pellet was collected by centrifugation at $12,400 \times \mathrm{g}$ for $15 \mathrm{~min}$ and rinsed with $70 \%$ ethanol before being air dried and resuspended in $30 \mu \mathrm{l}$ DEPC-treated water. For the FBT method, we followed the protocol from Kim et al. (2012) with some modifications. The algal cell pellet was resuspended in $1 \mathrm{ml}$ TriPure Isolation Reagent before adding 3 metal beads $(0.25 \mathrm{~g}, 4 \mathrm{~mm}$ in diameter) and proceeding to three cycles of snap freezing using liquid nitrogen, thawing in a $100^{\circ} \mathrm{C}$ heating block and finally beating for $1 \mathrm{~min}$ at 4,800 rpm using a Mini-beadbeater 1 (Biospec). For LNT, the algal cell pellet was ground using a mortar and a postal in presence of liquid nitrogen for approximately 2-3 $\mathrm{min}$ and transferred into a new $1.5 \mathrm{ml}$ microtube before mixing with 1 $\mathrm{ml}$ TriPure Isolation Reagent. The samples for FBT and LNT were added with $200 \mu \mathrm{l}$ chloroform and then processed in the same way as those for direct extraction. For LNK, the sample was ground in liquid nitrogen before being processed according to the RNeasy Plant Mini Kit protocol (Qiagen), using RLT buffer. The RNA was eluted in $30 \mu 1$ DEPCtreated water. One microgram of RNA was used for agarose gel electrophoresis and NanoDrop (Thermo Scientific). RNA was then subjected to DNaseI (New England Biolabs) treatment and purification using FavorPerp After Tri-Reagent RNA Clean-UP kit (Favorgen Biotech Corp) with elution volume at $50 \mu \mathrm{l}$. RNA was then analyzed again using NanoDrop, and one microgram of RNA was used for a quality check using agarose gel electrophoresis. rRNA ratio, RIN analysis and De Novo transcriptome
sequencing

RNA quality control, RNA-seq library preparation and highthroughput sequencing were performed by Macrogen Inc. In brief, total RNA was qualified on an Agilent Bioanalyzer 2100 using an RNA 6000 nano chip (Agilent Technologies). RNA-seq library was prepared from polyA + mRNAs using TruSeq mRNA library construction protocol (Illumina). High-throughput pair-end sequencing was performed on a HiSeq 2000 platform (Illumina). The quality of raw read data was accessed by FastQC program (http://www. bioinformatics.babraham.ac.uk/projects/fastqc/).

Trimmomatic program (http://www.usadellab.org/cms/? page=trimmomatic) was used to remove adapters from the raw reads. De novo transcriptome assembly was performed on trimmed reads using Trinity software (http://trinityrnaseq.sourceforge.net/).

\section{RT-PCR}

For cDNA synthesis, a reaction mixture including $1 \mu \mathrm{g}$ RNA, $2.5 \mu \mathrm{M}$ oligo $(\mathrm{dT})_{15-18}, 0.5 \mathrm{mM} \mathrm{dNTP}$ and DEPC water in 13 $\mu 1$ total volume was incubated at $65^{\circ} \mathrm{C}$ for $5 \mathrm{~min}$ and cooled down on ice before adding $4 \mu 15 \mathrm{X}$ reaction buffer, $1 \mu \mathrm{DTT}$, $1 \mu \mathrm{l}$ RNase inhibitor and $1 \mu \mathrm{l}$ Protoscript II Reverse Transcriptase (New England Biolabs). The mixture was incubated at $42^{\circ} \mathrm{C}$ for $60 \mathrm{~min}$ and then at $65^{\circ} \mathrm{C}$ for $20 \mathrm{~min}$. cDNA was then diluted 5 -fold before being used in PCR reactions. RT-PCR reaction mixture contained $1 \mu \mathrm{l} \mathrm{cDNA}$, $0.5 \mu \mathrm{M}$ for each primer, $100 \mu \mathrm{M}$ dNTPs, $1 \mathrm{X}$ Taq polymerase buffer and 0.5 unit Taq polymerase (New England Biolabs) in $20 \mu \mathrm{l}$ total volume. The primers are as follows: UBI primers (5'-CTCATCGTCTGCCAGTGTGT-3' and 5'TGTGGGTCTGTCGATCTTGC-3'), STAl primers (5'CAACGCGCTGATCATTGGAG-3' and 5'-ATGACCACGTTCTTGCCGAT-3') and STA6 primers (5'-GGCAGCGACTACTACGAGAC-3' and 5'-CTTGGGATGACGCTGTCCTT-3'). RT-PCR reaction was performed in conditions of 2 min at $94^{\circ} \mathrm{C}$ followed by 30 cycles of $30 \mathrm{sec}$ at $94^{\circ} \mathrm{C}, 30$ sec at $65^{\circ} \mathrm{C}$ and $30 \mathrm{sec}$ at $72^{\circ} \mathrm{C}$ and the final cycle at $72^{\circ} \mathrm{C}$ for $5 \mathrm{~min}$.

\section{Conclusion}

The LNT was proven to be the most effective method for extracting a large amount of high quality RNA required for transcriptome sequencing, even from oil rich microalgal cells. This method is attractive for its simple protocol, low cost set up suitable for small labs and the ease in processing a large sample without the need for splitting the sample into smaller fractions. However, one drawback of this method is its labor-intensive nature, which might not be suitable for a large number of samples. With the RNA yields obtained from seven microalgal species, our work provides some guidelines for the amount of starting materials for RNA isolation for transcriptome sequencing.

\section{Acknowledgements}

The authors thank Thailand Institute of Science and Technology Research (TISTR) for providing microalgal strains. We also thank Prof. Juergen Polle for Coelastrum sp. strain. 
This work was supported by PTT public company limited, Kasetsart University Research and Development institute (KURDI), Thailand Research Fund (TRF-TRG5780273).

\section{References}

Baba M, Ioki M, Nakajima N, Shiraiwa Y, Watanabe MM (2012) Transcriptome analysis of an oil-rich race A strain of Botryococcus braunii (BOT-88-2) by de novo assembly of pyrosequencing cDNA reads. Bioresource Technol. 109:282-286.

Dang PM, Chen CY (2013) Modified method for combined DNA and RNA isolation from peanut and other oil seeds. Mol Biol Rep. 40(2):1563-1568.

Domozych DS, Ciancia M, Fangel JU, Mikkelsen MD, Ulvskov P, Willats WG (2012) The cell walls of green algae: a journey through evolution and diversity. Front Plant Sci. 3:82.

Gallagher SR. Desjardins PR (2006) Quantitation of DNA and RNA with absorption and fluorescence spectroscopy. Curr Protoc Mol Biol. 76:3D:A.3D.1-A.3D.21.

Guarnieri MT, Nag A, Smolinski SL, Darzins A, Seibert M, Pienkos PT (2011) Examination of triacylglycerol biosynthetic pathways via de novo transcriptomic and proteomic analyses in an unsequenced microalga. PLoS One. 6(10):e25851.

Gwak Y, Hwang YS, Wang B, Kim M, Jeong J, Lee CG, Hu Q, Han D, Jinet E (2014) Comparative analyses of lipidomes and transcriptomes reveal a concerted action of multiple defensive systems against photooxidative stress in Haematococcus pluvialis. J Exp Bot. 65(15):4317-4334.

Johnson MTJ, Carpenter EJ, Tian Z, Bruskiewich R, Burris JN, Carrigan CT, Chase MW, Clarke ND, Covshoff, De Pamphilis CW, Edger PP, Goh F, Graham S, Greiner S, Hibberd JM, Jordon-Thaden I, Kutchan TM, LeebensMack J, Melkonian M, Miles N, Myburg H, Patterson J, Pires JC, Ralph P, Rolf M, Sage RF, Soltis D, Soltis P, Stevenson D, Stewart CN Jr, Surek B, Thomsen CJ, Villarreal JC, Wu X, Zhang Y, Deyholos MK, Wong GK (2012) Evaluating methods for isolating total RNA and predicting the success of sequencing phylogenetically diverse plant transcriptomes. PLoS One. 7(11):e50226.

Kim BH, Ramanan R, Cho DH, Choi GG, La HJ, Ahn CY, Oh HM, Kim HS (2012) Simple, rapid and cost-effective method for high quality nucleic acids extraction from different strains of Botryococcus braunii. PLoS One. 7(5):e37770.

Kirk MM, Kirk DL (1985) Translational regulation of protein synthesis, in response to light, at a critical stage of Volvox development. Cell. 41(2):419-428.
Lv H, Qu G, Qi X, Lu L, Tian C, Ma Y (2013) Transcriptome analysis of Chlamydomonas reinhardtii during the process of lipid accumulation. Genomics. 101(4):229-237.

Miller R, Wu G, Deshpande RR, Vieler A, Gärtner K, Li X, Moellering ER, Zäuner S, Cornish AJ, Liu B, Bullard B (2010) Changes in transcript abundance in Chlamydomonas reinhardtii following nitrogen deprivation predict diversion of metabolism. Plant Physiol. 154(4):1737-1752.

Ouyang LL, Chen SH, Li Y, Zhou ZG (2013) Transcriptome analysis reveals unique C4-like photosynthesis and oil body formation in an arachidonic acid-rich microalga Myrmecia incisa Reisigl H4301. BMC Genomics. 14(1):396.

Rismani-Yazdi H, Haznedaroglu BZ, Bibby K, Peccia J (2011) Transcriptome sequencing and annotation of the microalgae Dunaliella tertiolecta: pathway description and gene discovery for production of next-generation biofuels. BMC Genomics. 12(1):148.

Rismani-Yazdi H, Haznedaroglu BZ, Hsin C, Peccia J (2012) Transcriptomic analysis of the oleaginous microalga Neochloris oleoabundans reveals metabolic insights into triacylglyceride accumulation. Biotechnol Biofuels. 5(1):74.

Sambrook J, Russell DW (2001) Molecular Cloning. Cold Spring Harbor, NY: Cold Spring Harbor Press.

Sangha JS, Gu K, Kaur J, Yin Z (2010) An improved method for RNA isolation and cDNA library construction from immature seeds of Jatropha curcas L. BMC Res Notes. 3(1): 126 .

Schroeder A, Mueller O, Stocker S, Salowsky R, Leiber M, Gassmann M, Lightfoot S, Menzel W, Granzow M, Ragg T (2006) The RIN: an RNA integrity number for assigning integrity values to RNA measurements. BMC Mol Biol. 7(1):3.

Simon DF, Domingos RF, Hauser C, Hutchins CM, Zerges W, Wilkinson KJ (2013) Transcriptome sequencing (RNAseq) analysis of the effects of metal nanoparticle exposure on the transcriptome of Chlamydomonas reinhardtii. J Appl Environ Microbiol. 79(16):4774-4785.

Sun D, Zhu J, Fang L, Zhang X, Chow Y, Liu J (2013) De novo transcriptome profiling uncovers a drastic downregulation of photosynthesis upon nitrogen deprivation in the nonmodel green alga Botryosphaerella sudeticus. BMC Genomics. 14(1):715.

Thanh T, Omar H, Abdullah MP, Chi VTQ, Noroozi M, Ky H, Napis S (2009) Rapid and effective method of RNA isolation from green microalga Ankistrodesmus convolutus. Mol Biotechnol. 43(2):148-153. 